\title{
Research on the Necessity of Establishing the Pay-when-paid Mode of Educational Security Fund
}

\author{
Shuhong Liang \\ China University of Geosciences (Beijing), School of Humanities \&Economic Management, Beijing,
} 100083

\begin{abstract}
The property of public products of elementary education, the quasi-public products and the fairness principle of higher education determines that the investment in education must be coordinated by the government. Serious shortage of funding for education requires the State to raise education fund through a new channels. The establishment of pay-when-paid mode of educational security fund is an effective way to solve current educational problems.
\end{abstract}

Keywords: the public property of education, educational security fund, the pay-when-paid mode

\section{Introduction}

From the perspective of economic benefit, education cannot only bring private benefits, but also produce social benefits. The private beneficiary of education expenditure is the people received education and their families, while the social beneficiary is the society and the nation. For individuals and families, the improvement of education can bring increasing income and more job opportunities. For the society and the nation, the improvement in citizen's education means the increasing of intellectual level in the whole society, the progress of civilization and the enhancement of the country's overall development in science and technology as well as the capacity of product update, etc., which reflects in the enhancement in the overall strength of the country ultimately.
More importantly, investment in education will contribute to the achievement of both efficiency and equality. Particularly, the investment in primary education in rural areas will be able to improve the level of human capital of the children in these areas, strengthen their employment ability and expands their development space, thus creating conditions for narrowing the urban-rural gap. As early as 1964, Schulz makes it clear that the decisive factor to improve the welfare of the poor does not lies in space, energy and land, but the improvement of population quality as well as knowledge. In 1987, he further believes that for educated farmers, once they have an opportunity to invest and have effective stimulus, they can turn stone into gold.

Therefore, beginning with the social fairness and effectiveness, tries to explore a new mode of educational security fund-that is pay-when-paid, in view of the current condition with serious shortage of educational funds.

\section{The Necessity Of Educational Security Fund Raised By The State Uniformly}

\subsection{Public property of education in elementary education}

In accordance with the basic viewpoint of public finance, whether the government is involved in micro-economic activities has two bases. On one hand, the market cannot distribute resource effectively when there are market advantages or market failures, such as monopolies, public goods, externalities and information asymmetries, etc. The role of government is to make up for market failures (Musgrave calls it the financial allocation function of the government). 
On the other hand, even if the market allocation of resources is up to Pareto efficiency standards, it has no clear regulation whether the Pareto efficiency standards are desirable, as a code of ethics. But in reality, the goal is to achieve social justice. To achieve the objective of fairness and justice, government intervention is necessary (Musgrave labels it as financial distribution function of the government). Strictly speaking, compulsory education is not a pure public product, for it can enhance people's welfare. Since 19th century, the reason that more and more governments regard compulsory education as pure public product is mainly that it is generally accepted that compulsory education aims to establish a common educational experience, ensure common language and civic values as well as prepare for participation in the economic and political structure of mainstream society. This kind of role that compulsory education plays is irreplaceable by any other education in different stages. For the reason that the social benefits of compulsory education is far greater than the private benefits, the social optimal level cannot be reached if the education is provided by those who only care about their goals to maximize private interest with much loss of efficiency.

Equal opportunities for education: elementary education, as a pure public product, mainly relies on government funding. The current management system of elementary education is decentralization (decentralization means that transferring the responsibility and management of the education from central government to local governments. Usually, governments in different levels offer education funding and take responsibility of management for educations in different levels.) The Ministry of Education is responsible for all education and its primary responsibility is to plan and coordinate various levels of education. However, in rural areas, the county government is the main authority to guarantee education expenditure in senior high school, so is the town government for junior high school education expenditure and village government for education expenditure in primary school. Such distribution pattern of educational rights will lead to deviating from the principle of fairness, widening gap between urban and rural areas and aggravating farmers' burden, for the fact that the changes of schools' acts has diverse relation with separation of government' power and diverse policies. In other words, the higher the separation of power and diversity level is, the stronger motivation and more reasonable right for charging non-government funding, such as tuition fee. Therefore, from the perspective of equity between urban and rural areas, the elementary education in China needs unified investment and planning with the participation of the State.

\subsection{The quasi-public property of higher education}

Judging from the practice of countries in the world, higher education is used as a quasi-public product with higher degree of publicity and China is no exception. In theory, the characteristic of quasi-public products of higher education is determined by the rules and characteristics of itself.

- The existence of externality

There is an obvious positive externality in higher education (positive externality refers to the influence of benefit or cost on others or society by people's economic behavior. That is to say, the training of higher education can not only benefit individual, but also bring social benefits. This feature of higher education makes personal utility gained by market provider is less than the total benefits deserved because of benefit spill. Symmetry in cost benefit is a fundamental principle of market exchange. When personal benefits are less than the cost, the scale of higher education narrows the higher education market, resulting in the loss of welfare and efficiency in the whole society and further deepening of contradiction between supply and demand of higher education. Therefore, due to the spillover effects of higher education, we cannot rely on market entirely, which also decides that the government has to bear certain costs and responsibilities of higher education.

- Deviation from the principle of unfairness

The deviation from the principle of unfairness mainly reflects in some aspects. Firstly, due to the positive externality of higher education, it is difficult to measure the benefit of this part by currency for its market providers, resulting in a gap between benefit and burden and violation of the inner requirement of 
economic justice. Secondly, the publicity of such quasi-public products of higher education is much obvious (social benefit is far more than personal benefit), making this inequity more serious. Thirdly, for the direct beneficiaries of higher education, if higher education is fully market-oriented, they have to bear the full cost of higher education (now they just take a few). The income level determines people's spending for higher education. A large number of low-income people cannot afford the cost in the face of quasi-public products available in the market and lose opportunities for education. Thus, the gap will further enlarge and violate the principles of social equity. China has a lower GDP per capita and cannot blindly stress fully market-orientation of higher education. Fourthly, it is unfair that the operating cost of higher education is fully paid by the beneficiaries, because the taxed they (including parents of students) paid includes a part of higher education fees. The phenomena of "full payment" will result in a certain degree of "repeated payment". So, the fully market-orientation of higher education is contrary to goal of social justice.

\section{- Structural imbalance}

Under the condition of market economy, no matter what the product is provided, producers are always pursuing to maximize profits. Achieving the profit of the providers in the market of higher education maximally must provide more social education products of high demand. It specifically reflects in the setting of professional institutions in Ministry of Higher Education. For example, popular majors are preferred, and the basic necessary theories involving spiritual civilization and other social long-term development in humanities disciplines should be reduced or omitted. Otherwise, it will cause serious imbalance in the internal structure of higher education, and eventually impact the long-term development social economy. Therefore, the existence of this market failure also requires the remedy by government.

- The existence of danger

The risks of scientific and technological research institutions existed, especially the risk of development of applied technology. The field of higher education has always been a valued research base around the world and the home to many high-and-new technology and products. High risk of the work on high-and-new technology development is hard to fully accept or endured by the market. Therefore, great support is necessary by the government and public finances.

In conclusion, education, as a public product, should not be in excessive decentralization or rely too much on market. Both quasi-public products and pure public products are required a unified management method with the participation of the State, promoting social equity and reducing local differences.

\section{The Necessity Of Educational Security Fund}

\subsection{Lake of education investment}

Li Jinhua, auditor general of State Auditing Administration, on June 23, 2004, on the tenth meeting of the 10th National People's Congress of the Party Committee, reports the auditing information of central budget implementation and other financial revenues and expenditure in 2003 . He said that " it is found that there is heavy indebt in elementary education in the auditing surveys of elementary education expenditure in 17 provinces (autonomous regions and cities), 50 counties. The debt for elementary education in these 50counties is 2.348 billion Yuan at the end of 2001, increases to 3.1 billion Yuan at the end of 2002, growing by $30 \%$. At the end of June in 2003, it increases by $25.7 \%$ within just 6 months, reaching 3.898 billion Yuan. The growth rate of debt is considerably higher than that of education expenditure in the same period. The total debt is equivalent to $80 \%$ of fiscal revenue in a year in these regions. The debt for education also covers a lot of schools. More than $80 \%$ primary and secondary schools in some counties are in debt, which has become heavy burdens of governments at county and village level and schools."

Meanwhile, the investment in compulsory education in China is only more than $3 \%$ of China's GDP, far less than $6 \%$, the standard recommended by the United Nations. In 2003, the investment for rural compulsory education is 136.5 billion Yuan, 47.6 
billion Yuan less than the actual basic needs. In 2010, national financial education expenditure is only $3.66 \%$ of China's GDP; in 2012, this proportion is 4\%, though reached this goal, but also still below $6 \%$ of the United Nations Recommendations standards. It is obvious that the total investment is in serious shortage. Moreover, the system of county-oriented investment causes the problem that some counties which can just keep the operation of the government itself cannot assume responsibility for compulsory education investment. Therefore, some schools are in serious shortage of funds. Especially in some elementary and primary schools in less developed regions, when they charge for extras and books, sometimes they also charge for operating fees, funding, fees for remedial classes, materials, test papers as well as competitions, etc. in the name of various reasons. They regard it as one of the methods to support the development of schools, which will lead to the increasing of fees paid by students and parents, the increasing burden to thousands of civilian families. The children in poor areas are facing new challenges of receiving education, which directly involves the fairness of education.

Currently, China's education expenditure is largely dependent on State funding, mainly from State tax revenue. In 2000, our education expenditure occupies only $2.98 \%$ of GDP, about $4 \%$ lower compared to most South-East Asian countries in education investment, far from that in developed countries.

In conclusion, for the serious shortage in education funding, the government is required to take a more effective and fair method to raise education funding - establishing educational security fund.

\subsection{The method of raising educational security fund}

The main subjects in raising educational security fund: both sides of spouses who have children are obliged to pay basic educational security fund for their children.

The payment period of educational security fund: from the birth year to the age of 16 .

Fund-raising mode: the mode of fund-raising includes three levels; the first level is government leading and management. Basic educational security fund includes basic educational security fund for children of urban workers, children of employees in government institutions, children of soldiers and children of farmers. The second level is that enterprises are encouraged to offer educational security fund by using enterprise annuity for children of workers employed. The third level refers to individual commercial education insurance.

The first level in fund-raising mode, the main part with national mandatory, is the main source of basic educational security fund. The common obligation of both sides of the spouses who have children does not change with the marital relations. The second level, as the second pillar of basic educational security fund, is carried out by enterprises independently, followed by the principle of voluntariness. Enterprises can implement this benefit to staff according to their own financial situation, increasing their motivation for work. Great importance attached to the development of the third level contributes to the expansion in the coverage of educational security fund.

The distribution subject of educational security fund: the individual in compulsory education and higher education. The country provides living security funds based on the local minimum living standard monthly.

In addition, the country provides interest of educational security fund paid by citizens until the time that the subject is no longer of receiving education. The balance of the educational security fund will be classified into the individual account of social insurance.

\section{The management of educational security fund-establishing the pay-when-paid mode}

Establishing an educational security trust fund - an independent account to record the received fund and to pay allowance. The trust fund is different from government's independent account. The former is similar to a checking account, receiving fund monthly and distribute the same number allowance. The fund separates revenues and expenditures of educational security fund from government's general 
account. All the private and public sectors must participate in the basic educational security fund enforced by the country, which has only one system, one tax rate, one interest rate and one standard. The educational security fund is planned nationwide, with strong adjustment capacity. It is completely portable that any citizen can move to any place and receives educational security fund in any place.

\section{Prospect}

\subsection{Solving the shortage of funds effectively by educational security fund}

Twelve years compulsory education in China is exempt from tuition fees, but the main reason for rural poor students who can't afford their school is the cost of living expenditure. Educational security fund can solve this problem, improve and supplement the nine-year compulsory education. Besides, our country attaches great importance to higher education, providing national student loan and various scholarships for students with financial problems, but those provided are far from enough. The State regulates the upper limit for loan is 6,000 Yuan per year, which can barely afford tuition fees. Living expenditure remains the heavy burden and the factor of restricting poor students to school. But educational security fund can also solve the life problems for students receiving higher education. In this way, the project of educational security fund effectively links with the government investment for nine years compulsory education and the student loan system for higher education. It will guarantee national education and contributes to improving the quality of the nation.

The precondition for distributing security funds is that the children of payers are receiving education (including elementary education and higher education). As long as they are, the State provides higher interest for the security fund they pay, and if not, the State will not pay any interest for their remaining security fund. This policy will promote people to continue their school and is good for improving the national education level. The unified resource distribution by the State narrows the differences of regions, provides more opportunities for children in low-income families and promotes social equality and justice.

The mode of pay-when-paid in educational security fund can also be effective to alleviate the current situation of serious shortage of education funds. A fixed fund is for a fixed purpose, increasing the investment for education. Provided that the State sets up a perfect management system of allowance payment, guaranteed by relevant institutions, citizens are eligible to receive educational security fund anywhere.

\subsection{The restricted factors in the pay-when-paid mode of educational security fund project}

Low birth in population remains stable, The national total fertility rates in 2010 is 1.18 , the national total fertility rates of women in childbearing age in 2004, 2005 and the year surveyed before (from September in 2005 to August in2006) are 1.59、1.74 and 1.87 respectively, The total first marriage rates are $1.23 、 1.16$ and 1.11 respectively. The total one-child fertility rates are $1.07 、 1.23$ and 1.32 respectively, showing a certain degree of first marriage accumulation and birth accumulation.

Educational security fund project adopts pay-when-paid mode, that is to say, paying current education spending by using payers' future investment. However, judging from the data above, there is a certain degree of first marriage accumulation and birth accumulation currently. Therefore, there are potential shortages of project funding in the case of lower birth rate. The project needs to be improved a lot.

In addition, the incomes of China's urban and rural residents vary greatly. Taking the family income of urban residents in 2005 as an example, the disposable income in the highest $10 \%$ group of the urban household income is 28773 Yuan per capita annually, while the disposable income in the lowest $10 \%$ group is 3135 Yuan. If the basic educational security fund paid takes $5 \%$ of the disposable income per capita monthly, the disposable income in the highest $10 \%$ group is 2397.75 Yuan per capita monthly. The basic educational security fund paid by the couple monthly is $397.75 \times 5 \% \times 2=239.775$ Yuan, 
and $239.775 \times 12 \times 16=46036.8$ Yuan for 16 years. The disposable income in the lowest $10 \%$ group is 261.25 Yuan per capita monthly. The basic educational security fund paid by the couple monthly is $261.25 \times 5 \% \times 2=26.125$ Yuan, and $26.125 \times 12 \times 16=$ 5016 Yuan in 16 years. How to allocate educational security fund rationally and how to fulfill the redistribution function of social wealth are urgent issues in ensuring social equity.

In any case, the pay-when-paid mode of educational security fund system needs to be established in the current situation, comprehensively promote the pay-when-paid educational security fund, thus promoting the coordinated development of China's education and improve national competitiveness and qualities, so that we can solve the current situation of unfairness and insufficiency in education investment.

\section{References}

[1] N. Bruce, The public finance and economy of the United States of America, $2^{\text {nd }}$ ed., pp.21-22, 2005.

[2] Gao L.H. and Yang L., "The public product and market equilibrium of higher education", Occupation technology education (Teach Science Edition), pp.65-67, 2005.

[3] Jin L., "Changes and deciding factors of tuition in rural areas of West China", Chinese Public finance Reform: Challenges and measures, pp.3, 2007.

[4] Li X.Y., "The idea of public financial system of compulsory education in China under the framework of public finance", Chinese Public finance Reform: Challenges and measures, pp.1-2, 2007.

[5] Cui G.SH. "Analysis of the balanced development of compulsory education in the eastern developed area - taking the primary and high school in Beijing as an example", Chinese Public finance Reform: Challenges and measures, pp.4-5, 2007 